\title{
Cytogenetic Studies in Two Species of Genus Pimelodella (Teleostei, Siluriformes, Heptapteridae) from Iguatemi River Basin, Brazil
}

\author{
Carlos Alexandre Fernandes ${ }^{1,2}$, Jenifer Fernanda Damásio ${ }^{1 *}$, \\ Zaira da Rosa Guterres ${ }^{1,2}$, and Milza Celi Fedatto Abelha ${ }^{1,2}$ \\ ${ }^{1}$ State University of Mato Grosso do Sul, \\ BR 163-Km 20.2-CEP: 79980-000, Mundo Novo, MS, Brazil \\ ${ }^{2}$ Grupo de Estudo em Ciêcias Ambientais e Educação (GEAMBE)
}

Received October 5, 2012; accepted March 12, 2013

\begin{abstract}
Summary Pimelodella is one of the genera belonging to the family Heptapteridae consisting of endemic neotropical fishes; it has shown a wide variability in karyotype. The present study aimed to evaluate cytogenetically two species belonging to the genus Pimelodella from Iguatemi River Basin, MS, Brazil. In the specimens of P.avanhadavae, the diploid number was $2 n=52$ chromosomes, distributed in $24 \mathrm{~m}+20 \mathrm{sm}+08 \mathrm{st}$, with multiple NORs systems. The heterochromatin was weakly visualized with C-banding in telomeric and/or centromeric regions of a few chromosomes. For the specimens of $P$. gracilis, the diploid number was $2 n=46$ chromosomes, distributed in $20 \mathrm{~m}+18 \mathrm{sm}+$ $06 \mathrm{st}+2 \mathrm{a}$ to with a simple NORs system, and heterochromatic blocks in the centromeric and telomeric regions, with variable intensity of staining, and conspicuous interstitial blocks. The two species of Pimelodella differ in diploid number and karyotypic formula, indicating that chromosomal rearrangements, such as fissions and/or centric fusions, may have occurred during the diversification of these two species.
\end{abstract}

Key words Pimelodella avanhandavae, Pimelodella gracilis, Chromosomes, Chromosomal rearrangements, Karyotypic evolution.

Pimelodella is one of the genera belonging to the family Heptapteridae consisting of endemic neotropical fishes. It has a wide distribution in streams of Central and South America, and several representatives of specific locations in areas of endemism have been recognized ichthyologically (Bockmann and Guazelli 2003). It includes fish both small and medium sized, representing one of the largest radiations of catfishes (de Pinna 1998).

Despite recently being elevated to the status of family, Heptapteridae, which until recently were considered a subfamily of Pimelodidae, cytogenetic studies have since 1976, first was in Rhamdia hilarii and Pimelodella sp. However, of the 26 genera belonging to the family Heptapteridae, only seven genea have been studied cytogenetically, and of 200 species only 17 species are characterized cytogenetically (Borba 2009). Existing cytogenetic reports on the genus Pimelodella show great variability in karyotype, with diploid numbers ranging from $2 n=46$ in Pimelodella sp. (Vasconcelos and Martins-Santos 2000, Vissoto et al. 1999) to $2 n=58$ in P. kronei (Almeida-Toledo et al. 1992).

The genus Pimelodella is characterized by a karyotype mainly formed by pairs of metacentric and submetacentric chromosomes, with subtelocentric and acrocentric chromosomes occurs the least, while maintaining a high number of fundamental arms, ranging between 80 and 116 (Swarça

* Corresponding author, e-mail: fxande@gmail.com

DOI: $10.1508 /$ cytologia.78.91 
et al. 2003). Sex chromosomes systems of type XX/XY were described by Dias and GiulianoCaetano (2002) in Pimelodella sp. and more recently been found in P. boshimai as a sexual system of the type $\mathrm{X}^{1} \mathrm{X}^{1} \mathrm{X}^{2} \mathrm{X}^{2} / \mathrm{X}^{1} \mathrm{Y}^{1} \mathrm{X}^{2} \mathrm{Y}^{2}$ (Garcia 2005).

Considering the absence of cytogenetic information on the Pimelodella genus from the Iguatemi River basin and the broad karyotype variation found in this genus, this study is an attempt to conduct a chromosome characterization of $P$. avanhandavae and $P$. gracilis in order to contribute new cytogenetic data on this group.

\section{Materials and methods}

P. avanhandavae (7 males, 5 female, and 3 indeterminate sex) and $P$. gracilis (4 males, 4 female, and 4 indeterminate sex) were collected from the Água Boa stream (23'50"16, 65"S and $54^{\circ} 20^{\prime} 55^{\prime \prime}, 54^{\prime \prime} \mathrm{W}$ ) a tributary of the Iguatemi River (Mundo Novo, MS, Brazil).

The fishes were identified and deposited in the State University of Mato Grosso do Sul, unit Mundo Novo. Before being eviscerated to obtain the chromosomes, the fishes were anesthetized by an overdose of clove oil (Griffiths 2000). Metaphase chromosomes were obtained from anterior kidney cells using the air-drying technique (Bertollo et al. 1978). Analysis of the C-positive heterochromatin (C-bands) followed the basic procedure of Sumner (1972), with some minor adaptations. The NORs were detected by means of silver nitrate staining (Ag-NORs), according to Howell and Black (1980).

About 30 metaphases were analyzed for each specimen and those with a better quality were employed for karyotype analysis. The chromosomes were classified as metacentric (m), submetacentric (sm), subtelocentric (st), and acrocentric (a) according to their arm ratio (Levan et al. 1964). For the determination of the fundamental number (FN), or number of chromosome arms, the $\mathrm{m}$, sm, and st chromosomes were considered as bearing two arms and the acrocentric chromosomes only one arm.

\section{Results}

$P$. avanhandavae presented a modal diploid number of $2 n=52$ chromosomes in males and females, distributed in $24 \mathrm{~m}+20 \mathrm{sm}+08 \mathrm{st}$, with a FN of 104 , with no morphological chromosome difference between the sexes (Fig. 1A). In P. gracilis, the diploid number was $2 n=46$ chromosomes, distributed in $20 \mathrm{~m}+18 \mathrm{sm}+06 \mathrm{st}+2 \mathrm{a}$, with a FN of 90 , with no morphological chromosome difference between the sexes (Fig. 1B).

The Ag-NORs were located in a telomeric position on the short arm of one subtelocentric pair and in a telomeric position on the long arm of one acrocentric pair in P. avanhandavae (Fig. 2A), and were located in a telomeric position on the short arm of one metacentric chromosome in $P$. gracilis (Fig. 2B).

In $P$. avanhandavae, the heterochromatin was weakly visualized with C-banding in the telomeric and/or centromeric regions of a few chromosomes (Fig. 2C). While in P. gracilis, heterochromatic blocks were observed at the centromeric and telomeric regions of a few chromosomes, with variable intensity of staining, and conspicuous heterochromatic blocks were observed at pericentromeric regions in 1 submetacentric pair (Fig. 2D).

\section{Discussion}

The present diploid number obtained in the species $P$. avanhandavae corroborates with those previously reported for $P$. avanhandavae (Swarça et al. 2003). However, distinct karyotypic formulae were observed, principally in relation to subtelocentric chromosomes found in the present study, 


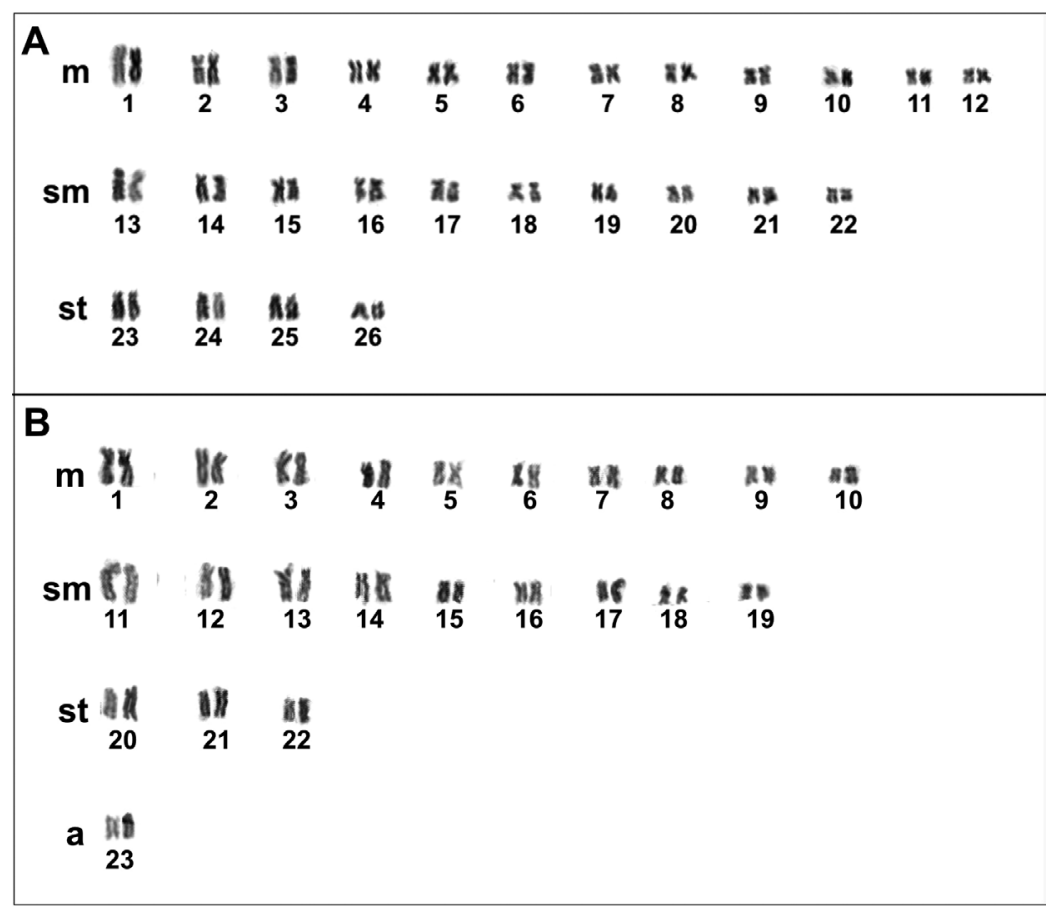

Fig. 1. Conventional Giemsa-stained karyotypes of (a) Pimelodella avanhandavae and (b) Pimelodella gracilis.

which were not described for the populations previously evaluated. In contrast to $P$. avanhandavae, the present population of $P$. gracilis showed a different diploid number, namely $2 n=46$ chromosomes; this number of chromosomes had been found in Pimelodella sp. (Dias and Foresti 1993) and P.meeki (Vidotto et al. 2004). Although the diploid number is equal to these three species of Pimelodella, their karyotypic constitutions are different, with an FN of 90 for the P. gracilis analyzed here and FNs of 92 for both Pimelodella sp. and P. meeki (Dias and Foresti 1993, Vidotto et al. 2004). In the Pimelodella species, the numerical maintenance coupled with variation in karyotypic formulae could represent the occurrence of structural rearrangements, such as inversion and/ or translocation. On the other hand, in the Pimelodella species, as seen in P. avanhandavae and $P$. gracilis, diploid numbers differ, indicating that chromosomal rearrangements, such fissions and/ or centric fusions, may have occurred during the diversification of these two species. Therefore, the results obtained suggest that the species of the genus Pimelodella have undergone divergent karyotypic evolution.

By silver nitrate staining, the $P$. avanhandavae specimens here analyzed presented multiple NORs, while a single pair was detected in the population of $P$. avanhandavae from Tibagi River (Swarça et al. 2003) after it was analyzed for Ag-NOR, CMA 3 and rDNA-18S, suggesting different numbers of rDNA cistrons among individuals. Simple NORs were also detected in the present study in specimens of $P$. gracilis, as has previously been seen in $P$. gracialis (Garcia and AlmeidaToledo 2010), P. boshimai (Roman and Margarido 2002) and P. kronei (Almeida-Toledo et al. 1992). A single chromosome pair bearing NORs is a common feature shared by several Heptapteridae (Swarça et al. 2003, Stolf et al. 2004).

The C-banding revealed a small amount of constitutive heterochromatin in the studied species; these results were also similar to those described previously for other populations of Pimelodella (Swarça et al. 2003, Garcia and Almeida-Toledo 2010). Furthermore, in P. avanhandavae, the 

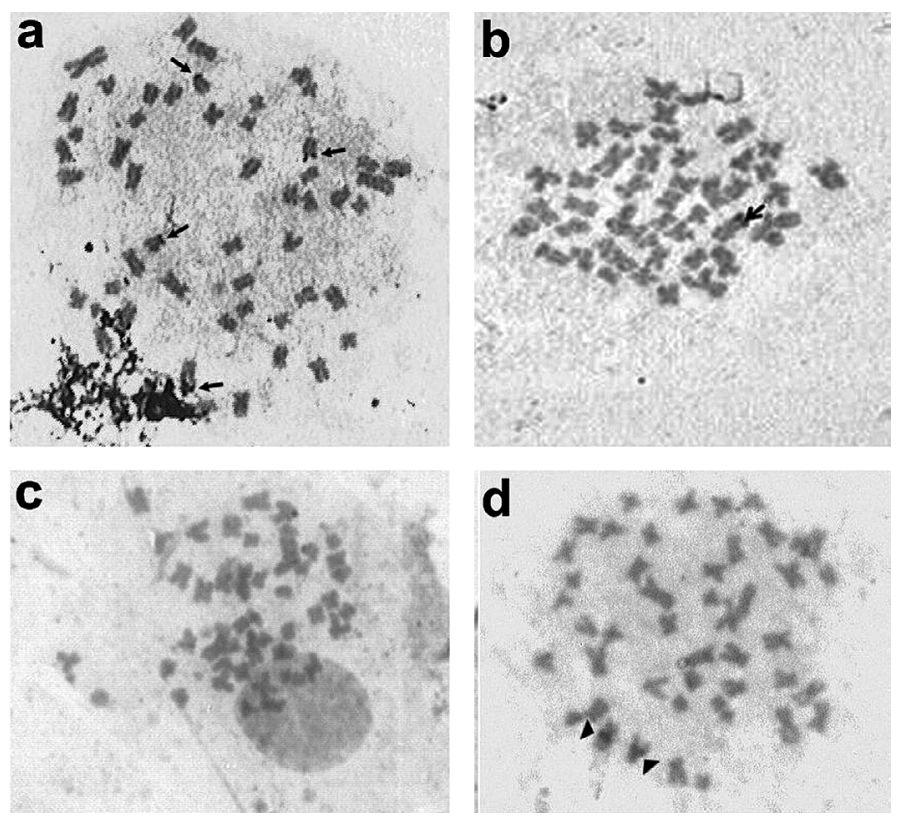

Fig. 2. Ag-NORs of (a) Pimelodella avanhandavae and (b) Pimelodella gracilis. Distribution pattern of constitutive heterochromatin in (c) Pimelodella avanhandavae and (d) Pimelodella gracilis. The arrows indicate the sites of Ag-NORs and arrowheads indicate interstitial heterochromatic blocks.

presence of metacentric pairs with conspicuous bi-telomeric C-bands, as seen in previous studies in this species (Swarça et al. 2003), was not detected. In P. gracilis, only one chromosomal pair bore intersticial C-bands, while $P$. gracialis presented two chromosomal pairs bearing interstitial C-bands (Garcia and Almeida-Toledo 2010). The occurrence of interstitial heterochromatic blocks in Pimelodella allows the differentiation of species and populations.

The present paper showed that $P$. avanhandavae and $P$. gracilis, despite morphologically being very similar, cytogenetically can easily be separated by differences in diploid number and the presence of interstitial heterochromatic blocks. These results are testament to the fact that cytogenetics can help to clarify taxonomic identification.

\section{Acknowledgements}

The authors thank the Brazilian agency Fundação de Apoio ao Desenvolvimento do Ensino, Ciência e Tecnologia do Estado de Mato Grosso do Sul (FUNDECT) for financial support.

\section{References}

Almeida-Toledo, L. F., Foresti, F., Trajano, E., and Toledo-Filho, A. S. 1992. Cytogenetic analysis of the blind catfish Pimelodella kronei and of its presumed ancestor Pimelodella transitoria. Caryologia 45: 255-262.

Bertollo, L. A. C., Takahashi, C. S., and Moreira-Filho, O. 1978. Cytotaxonomic considerations on Hoplias lacerda (Pisces, Erythrinidae). Rev. Bras. Genet. 1: 103-120.

Bockmann, F. A., and Guazelli, G. M. 2003. Heptapteridae. In: Reis, R. E., Kullander, S. O., and Ferraris, Jr., C. J. (eds.). Check list of Freshwater Fishes of South and Central America (CLOFFSCA), $1^{\text {st }}$ edition. Edipucrs, Porto Alegre. pp. 406-431.

Borba, R. S., Parise-Maltempi, P. P., and Alves, A. L. 2009. Tendência da evolução cariotípica na família Heptapteridae (Teleostei: Siluriformes). In: Resumos do $55^{\circ}$ Congresso Brasileiro de Genética. Águas de Lindóia. 
Dias, A. L., and Giuliano-Caetano, L. 2002. Citogenética de alguns grupos de peixes do rio Tibagi. A Bacia do Rio Tibagi. EDUEL, Londrina. pp. 473-529.

Dias, A. L., and Foresti, F. 1993. Cytogenetic studies on fishes ot the family Pimelodidae (Siluroidei). Rev. Bras. Genet. 16 $585-600$.

Garcia, C. 2005. Contribuição aos estudos citogeneticos em algumas espécies de 5 familias de Siluriformes do rio São Francisco. Dissertação de Mestrado, Universidade Federal de São Carlos, São Carlos.

Garcia, C., and Almeida-Toledo, L. F. 2010. Comparative chromosomal analyses in species of the genus Pimelodella (Siluriformes, Heptapteridae): occurrence of structural and numerical polymorphisms. Caryologia 63: 32-40.

Griffiths, S. P. 2000. The use of clove oil as an anaesthetic and method for sampling intertidal rockpool fishes. J. Fish Biol. 57: 1453-1464.

Howell, W. M., and Black, D. A. 1980. Controlled silver-staining of nucleolus organizer regions with a protective colloidal developer: a 1-step method. Experientia, 81: 1014-1015.

Levan, A., Fredga, K., and Sandberg, A. A. 1964. Nomenclature for centromeric position on chromosomes. Hereditas 52: 201-220.

De Pinna, M. C. C. 1998. Phylogenetic relationships of Neotropical Siluriformes (Teleostei, Ostariophysi): Historical overview and synthesis of hypotheses. In: Malabarba L. R., Reis R. E., Vari R. P., Lucena Z. M. S., and Lucena C. A. S. (eds,), Phylogeny and Classification of Neotropical Fishes. EDIPUCRS, Porto Alegre. pp. 279-330.

Roman, M. P., and Margarido, V. P. 2000. Estudos citogenéticos em três gêneros de Siluriformes (PISCES) coletados no rio Iguaçu—Quedas do Iguaçu Paraná. Dissertação de Mestrado, Universidade Federal de São Carlos, São Carlos.

Stolf, R., Swarça, A. C., Giuliano-Caetano, L., and Dias, A. L. 2004. Analysis of karyotype and nucleolus organizer regions of Imparfinis aff. shubarti (Siluriformes, Pimelodidae) of the Tibagi river basin, Paraná, Brazil. Caryologia 57: 348-352.

Summer, A. T. 1972. A simple technique for demonstrating centromeric heterochromation. Exp. Cell Res. 75: 304-306.

Swarça, A. C., Vidotto, A. P., and Dias, A. L. 2003. Cytogenetic characterization of Pimelodella avanhandave (Siluriformes, Pimelodidae) from Tibagi River (Paraná state, Brazil). Caryologia 56: 421-425.

Toledo, V., and Ferrari, I. 1976. Estudo citogenético de Pimelodella sp. e Rhamdia hilarii (Pimelodinae, Pimelodidae, Pisces): Cromossomo marcador. Científica 4: 120-123.

Vasconcelos, C., and Martins-Santos, I. C. 2000. Chromosome polymorphism in species of the Pimelodidae family (Pisces, Siluriformes). Hereditas 137: 103-107.

Vidotto, A. P., Swarça, A. C., Fenocchio, A. S., and Dias, A. L. 2004. Cytogenetic studies in three Pimelodella meeki populations (Pisces, Pimelodidae) from Tibagi river basin (Brazil). Hereditas 95: 517-520.

Vissoto, P. C., Foresti, F., and Oliveira, C. 1999. Karyotype description of five species of Pimelodidae (Teleostei, Siluriformes). Chromosome Science 3: 1-7. 